administrative orders would serve the public interest as well as the threat of criminal indictments and treble damages. Expert consideration of the vexatious problems would offer more hope of an answer than dismissing them simply as illegal restraints of trade.

\title{
THE NEW YORK ANTI-INJUNCTION ACT
}

IN 1935 New York joined those jurisdictions which have sought to curb by legislation the evils of the labor injunction. ${ }^{1}$ The New York Statute, Section 876 (a) of the Civil Practice Act, was modeled after the federal Norris-LaGuardia Act, ${ }^{2}$ but it seems to have produced a less notable improvement in existing labor law. The federal Act, passed to remedy the harm caused labor organization by courts which had taken a broad view of their power to intervene by the injunctive device, has worked a considerable change in judicial practice and attitude, and has triumphantly weathered an early disposition on the part of the courts to cripple some of its provisions by narrow construction. ${ }^{3}$ The New York Statute was launched in a state where the highest court had taken a liberal attitude towards labor, but where uncertainties in the law and illiberal ideas in many of the lower courts had created critical problems. The Court of Appeals, which had a well-deserved reputation as the outstanding liberal court of the country in labor questions, had pursued in general a hands-off policy towards normal union activities. Striking, picketing, organization and other peaceful union operations were permitted, not only in disputes between employer and employee, but also in campaigns for unionization and for the enforcement of union rules and standards. 5 The court permitted the closed shop, and the refusal of union men to work on non-union made materials and with non-union men. ${ }^{\mathfrak{b}}$ On

1. N. Y. Civ. PRAC. Act \$ 876(a), N. Y. Laws 1935, c. 477.

2. 47 StAT. 70 (1932), 29 U. S. C. \$101 (1938).

3. See (1938) 2 MO. L. REv. 1. The Supreme Court has checked the disposition of certain cases in the Seventh Circuit to give the labor disputes definition an unduly narrow construction. Lauf v. Shinner, 303 U. S. 323 (1938), rev'g $\& 2$ F. (2d) 68 (C. C. A. 7th, 1936). The Court recognized that the purpose of the Statute was to extend the Clayton Act limitation on labor injunctions and to "obviate the results of the judicial construction of that act." New Negro Alliance v. Sanitary Grocery Co., 303 U. S. 552, 562 (1937).

4. The New York court may recently have been succeeded by the Wisconsin court. See (1936) 5 Int. Jurid. Ass'N Burl. 59, (1939) \& Int. Jurip. Ass': Belz. 29.

5. T. H. \& S. Theatres v. Fay, 260 N. Y. 315,183 N. E. 509 (1932); Stillwell Theatres v. Kaplan, 259 N. Y. 405,182 N. E. 63 (1932), cert. desided, 283 U. S. 605 (1932), 46 HARV. L. Rev. 125; Exchange Bakery \& Restaurant v. Riflin, 245 N. Y. 260, 157 N. E. 130 (1927) ; National Protective Ass'n v. Cumming, 170 N. Y. 315, 63 N. E. 369 (1902).

6. Bossart v. Dhuy, 221 N. Y. 342,117 N. E. 582 (1917); National Protective Ass'n v. Cumming, 170 N. Y. 315, 63 N. E. 369 (1902); IVilliams v. Quill, 227 X. Y. 1,12 N. E. (2d) 547 (1938). See (1939) \& Int. Junm. Ass's BurL 38. 
the other hand, many of the lower courts, in which injunction proceedings arise and in which, most of them are finally disposed of, adopted an unduly restrictive position with respect to labor activities.

The Court of Appeals had difficulty in controlling this restrictive tendency, either in appeal proceedings or by means of the doctrine of stare decisis. The ruling cases attempted to mark off the boundaries of permissible union activity by such vague criteria as "peaceful persuasion and publicity" contrasted with "violence or intimidation;" " "inducement to breach of contract" as opposed to "urging the recission or modification of a contract:" and in the case of union objectives, "malice" or "intent to injure the employer" as against "pursuit of benefit to labor."9 These terms had no fixed content from case to case; their unreality when applied by the lower courts to a tense labor dispute situation was often clear. Nor did direct appeal prove much more satisfactory than stare decisis as a mechanism of control. The scope of review was necessarily limited by the discretionary character of the injunctive remedy, while the conventional language used by the lower courts in their findings on complex labor issues often failed to provide the appellate court with sufficient information on which to base an intelligent decision. Since the element of time is often vital to the success of union activities, the delays of appeal were a serious defect; where, as in the case of many preliminary injunctions, the decree was based on inadequate evidence or on ex parte affidavits which were "in part unfounded and in part grossly exaggerated," 10 an eventual reversal was small comfort to a union which had lost a strike in the meantime.

Against this background, the New York Statute seems to have been aimed not so much at a modification of the Court of Appeals' doctrines, as at compelling the lower courts to conform to those doctrines by making governing principles more certain, by insuring adequate consideration of the cases and by curbing the discretion of the trial courts. It was hoped that in this way the number of injunctions granted would be sharply reduced, since they would issue only where clearly necessary. ${ }^{11}$ The Statute seeks to reach these objectives by employing two main devices. First, it deprives the New York courts of jurisdiction to issue injunctions except where a considerable list

7. J. H. \& S. Theatres v. Fay, 260 N. Y. 315,183 N. E. 509 (1932).

8. Interborough Rapid Transit Co. v. Lavin, 247 N. Y. 65,159 N. E. 863 (1928).

9. Bossart v. Dhuy, 221 N. Y. 342,117 N. E. 582 (1917); National Protective Ass'n v. Cumming, 170 N. Y. 315,63 N. E. 369 (1902).

10. Frankenthaler, J., in Tree-Mark Shoe Co. v. Schwartz, 139 Misc. 136, 138, 248 N. Y. Supp. 56, 58 (Sup. Ct. 1931). The court here modified a preliminary injunction granted at Special Term removing the ban on all picketing.

11. This expectation was largely realized. The number of injunctions granted in labor disputes in New York decreased from about 100 per year to 10 per year in the first year of the Statute. Note (1936) 46 Yale L. J. 1064, 1066, n. 13; (1936) 5 INT. JURID. Ass's Bull. 5. 
of pre-requisite facts is pleaded and proved ;2 second, it provides that no relief granted should prohibit striking, picketing, organization, combination or other accepted union activities. ${ }^{13}$

The list of required findings proved fairly successful in curbing the discretion of the trial courts. A degree of restraint in the use of labor injunctions was enforced which, although justifiable under the doctrines of the Court of Appeals, ${ }^{14}$ was not general, or even usual, in lower court practice. The Statute further bolsters its requirements of adequate evidence and findings by providing, in the case of preliminary injunctions, for a hearing excluding affidavits, and by compelling the petitioner to post a bond for injuries which may result to his opponent from an unjustified temporary injunetion. ${ }^{15}$ The limitations on the relief which may be granted also reduce judicial discretion, and for the first time specifically outlaw the sweeping "blanket" injunction which may prohibit, in a given situation, almost all union activity. ${ }^{16}$

The general success of this statutory mechanism has been most marked in the simple situation of a dispute between an employer and his employees. Peaceful union activities are concededly legitimate, and violence and intimidation concededly enjoinable ${ }^{17}$ in the already clear legal principles applicable

12. N. Y. CTV. PRAC. ACr. $\$ 876(a) 1$ provides that no court shall have jurisdiction to issue any injunction, permanent or temporary, except after a hearing and after finding and filing in the record the following facts: that unlawful acts, or a breach of a contract not contrary to public policy, will occur or will continue unless restrained; that there will be substantial or irreparable injury to complainant unless the relief is granted; that a greater injury will be worked on complainant by denying each item of the relief than will be suffered by defendant if it is granted; that complainant has no adequate remedy at law, and that the police cannot furnish complainant adequate protection.

13. N. Y. CIv. PrAC. ACT $\$ 876$ (a)1(f).

14. The justification is to be found more from the spirit of these doctrines than from their specific content. There was, at first, a tendency to regard the requirement that the equities be balanced, supra note 12, and that the police protection is insdequate, supra note 12 , as making a change in the substantive law. This was done to deny these provisions retroactive effect. Micamold Radio Co. v. Beedie, 156 Misc. 390,282 N. Y. Supp. 77 (Sup. Ct. 1935), 35 CoL. L. Rev. 1147; accord, National House Cleaning Contractors, Inc. v. Babaluc, 251 App. Div. 401, 296 N. Y. Supp. 673 (1st Dep't 1937). As soon as the problem of retroactive application disappeared, however, the courts ceased to regard these provisions as changing the substantive law. Remington Rand, Inc. Crofoot, 248 App. Div. 356, 289 N. Y. Supp. 1025 (4th Dep't 1936), aff'd sithous opision, 279 N. Y. 635, 18 N. E. (2d) 37 (1938) ; Aberdeen Restaurant Co. v. Gotiried, 158 Misc. 785, 285 N. Y. Supp. 832 (Sup. Ct. 1935) ; DeAgostina v. Holmden, 157 Afise. 819, 285 N. Y. Supp. 909 (Sup. Ct. 1935).

15. N. Y. CIv. PRAC. ACT $\$ 876$ (a)3. Paragraph seven of the Statute provides that all temporary injunctions shall expire within ten days. The maximum duration of prrmanent injunctions is six months, with the possibility of renewal for another six months after hearing. N. Y. CTV. PRAC. ACT \$ \$76(a)\&.

16. N. Y. Civ. PrAC. ACT $\$ 876(a) 1(f)$.

17. This has been settled law in New York for a considerable pericd. In National Protective Ass'n v. Cumming, 170 N. Y. 315, 63-N. E. 369 (1902), the court felt able 
to this situation, the Act, therefore, makes little change. It does, however, confront the applicant for injunctive relief with formidable obstacles at the outset, and requires him to show clearly the justification for his petition. The relief may go no further than the situation warrants, the ex parte preliminary injunction is unavailable, and the possibility of intervention by an anti-labor judge is greatly reduced.

In more complex fact situations, where the pre-existing law was less certain and definite, the Statute has been considerably less successful. This comparative failure appears to have resulted from the so-called "declaratory" doctrine. The Court of Appeals in Goldfinger v. Feintuch, ${ }^{18}$ the case in which it first considered the Anti-Injunction Act, suggested that the Statute might be only declaratory of existing law. "Declaratory," however, is a rather vague word. It might mean simply that the requirements of the Statute codified and applied the principles behind the later Court of Appeals cases. But the lower courts, which from the start enthusiastically adopted the declaratory approach, ${ }^{19}$ gave the term quite a different meaning. They interpreted the Statute as merely regulating the procedure of injunction actions, without making any change in the substantive rights of the parties. ${ }^{20}$ This view has created serious problems. The constitution of New York is said to prohibit legislative curtailment of the jurisdiction of the New York Supreme Court, ${ }^{21}$ so that if the Statute is purely procedural, it cannot go far beyond previous decisions in limiting the injunctive power. The procedural emphasis, by retaining these decisions as governing authorities with respect to sub-

to include the general doctrine in a statement of principles of law assumed to be correct without demonstration. Id. at $320,63 \mathrm{~N}$. E. at 372 .

18. 276 N. Y. 281, 11 N. E. (2d) 910 (1937).

19. May's Furs and Ready-to-Wear, Inc. v. Bauer, 255 App. Div. 643, 8 N. Y. S. (2d) 819 (2d Dep't 1939) ; Remington Rand, Inc. v. Crofoot, 248 App. Div. 356, 289 N. Y. Supp. 1025 (4th Dep't 1936), aff'd without opinion, 279 N. Y. 635,18 N. E. (2d) 37 (1938) ; Everett v. Penna, 168 Misc. 589, 6 N. Y. S. (2d) 630 (Sup. Ct. 1938); Greater City Master Plumber's Union v. Kahme, 6 N. Y. S. (2d) 589 (Sup. Ct. 1937) (the Act merely prevents the granting of injunctions lightly or informally).

20. The cases cited supra note 19 are in point here. See Note (1936) 46 YALE L. J. 1064 ; Legis. (1935) 22 VA. L. REv. 83.

21. The constitutional provision referred to, which merely grants the Supreme Court "general jurisdiction in law and equity" [N. Y. CONST. ART. 6, \&1] is interpreted as not preventing legislative regulation of remedies within such reasonable limits as preserve to plaintiff substantial equitable protection in the courts. Matter of Stillwell, 39 N. Y. 337, 34 N. E. 777 (1893) ; People ex rel. Swift v. Luce, 204 N. Y. 478, 97 N. E. 850 (1912); People ex rel. Durham Realty Corp. v. La Fetra, 230 N. Y. 429, 130 N. E. 601 (1921). The Anti-Injunction Act is held to be within these limits. Goldfinger v. Feintuch, 276 N. Y. $281,289,11$ N. E. (2d) 910,914 (1937). The constitutional requirement is, however, advanced to support the declaratory doctrine, and to limit the scope of possible changes in the equity jurisdiction of the Supreme Court. Busch Jewelry Co. v. United Retail Employee's Local, 281 N. Y. 150, 155, 22 N. E. (2d) 320, 322 (1939); Aberdeen Restaurant v. Gotfried, 158 Misc. 785, 285 N. Y. Supp. 832 (Sup. Ct. 1935); Stalban v. Friedman, N. Y. L. J., April 3, 1939 (Sup. Ct. 1939). 
stantive law, retains also the confusing standards they created in the more complex labor situations such as those which arise in connection with "yellow dog" or closed shop contracts. This Comment is not concerned primarily with the enforcement of such contracts between the immediate parties, or with the difficult question of appropriate remedies; $;$ it is concerned with the situation where a union seeks, by organization or other activity, to bring about a result incompatible with the contract. The courts, in attempting to reconcile the illegality of "inducing breach of contract" and the general permissibility of peaceful union activities in industry, have introduced a good deal of confusion into the law. There was no clear decision in the Court of Appeals as to a union's right to picket to induce breach of contract, ${ }^{23}$ but it was held that a union might picket to inform the public that it regarded the contract as contrary to the interests of labor, that it might urge recission of the contract or that it might urge employees to resign and thus regain their freedom to join it. Interborough Rapnd Transit v. Lavin 24 is a particularly confusing decision along this line, since the court declined to decide what would be the result if the employees secretly joined and did not resign. Stillwell Theatres $v$. Kaplan ${ }^{25}$ set forth what was probably the controlling factor in the Court of Appeals' decisions, a reluctance to intervene in economic controversies. On the other hand, since there was no controlling rule on picketing to induce breach of contract, some of the lower courts could, and did, enjoin the picketing and other activities, often using also the alternative ground of irreparable injury to the employer. ${ }^{20}$ There there was a "yellow-dog contract," forcing employees to agree not to become or remain members of a labor organization, or where the employer issued orders to this effect and enforced them by dismissals, there seems to have been a tendency to permit union pressure on one of the grounds suggested by the Court of Appeals. On the other hand, where there was inter-union rivalry, the situation was more doubtful, since the position of the employer, caught between the lines and unable to satisfy both unions, aroused more judicial sympathy. ${ }^{27}$ This sympathy was particularly pronounced where the employer

22. See Witmer, Collective Labor Agreements in the Courts (1938) 48 YALE L. J. 195; Schlesinger v. Quinto, 201 App. Div. 487, 194 N. Y. Supp. 401 (1st Dep't 1922); Goldman v. Cohen, 222 App. Div. 631, 227 N. Y. Supp. 311 (1st Dep't 1928) (injunction against violation by employer). See Grassi Construction Co. v. Bennett, 174 App. Div. 244, 160 N. Y. Supp. 269 (1st Dep't 1916) (violation by employee).

23. In Exchange Bakery \& Restaurant Co. v. Riflin, 245 N. Y. 260,157 N. E. 130 (1927), decision was expressly reserved on this question.

24. 247 N. Y. 65,159 N. E. $\$ 63(1928)$.

25. 259 N. Y. $405,412,182$ N. E. 63,66 (1932), cert. denird, 298 U. S. 605 (1932).

26. Wolechak v. Wiseman, 145 Misc. 26S, 259 N. Y. Supp. 225 (Sup. Ct. 1932); Esco Operating Co. v. Kaplan, 144 Misc. 646, 258 N. Y. Supp. 303 (Sup. Ct. 1932); Hertzog v. Cline, 131 15isc. S16, 227 N. Y. Supp. 462 (Sup. Ct. 1927); Altman v. Schlesinger, 204 App. Div. 513, 198 N. Y. Supp. 12S (1st Dep't 1923).

27. See Stalban v. Friedman, N. Y. L. J., April 3, 1939 (Sup. Ct. 1939), 34 In工. L. Rev. 536; Hertzog v. Cline, 131 Mtisc. 816, 227 N. Y. Supp. 462 (Sup. Ct. 1927). 
was liable to penalties for breach of contract with the union in possession if he granted its rival's demands. In many cases, however, he had brought the situation on himself, not only by failing to foresee it and take proper precautions, but also by rushing to sign a contract with a complacent, if not employer-dominated group, in order to stave off unionization by an active and independent rival. Even in the presence of this rivalry, the Court of Appeals declined to intervene. ${ }^{28}$ Yet many of the lower courts were not so hesitant.

Section 876(a) of the Civil Practice Act, in conjunction with the State and Federal Labor Relations Acts, has cleared up part of the difficulty by making yellow-dog contracts and orders by the employer to the same effect, unenforceable and invalid. ${ }^{29}$ With respect to inter-union rivalry in the presence of contracts, the principles of the Statute seem to follow the doctrine of the Stillwell case, since inducing breach of a "valid and subsisting contract" 30 is one of the grounds for which an injunction may be granted; but the relief may not prohibit peaceful picketing and publicity. ${ }^{31}$ The confusing criteria of the cases retained under the declaratory doctrine make it quite probable, however, that lower courts will persist in enjoining union activity where there is inter-union rivalry.

The continued reliance on past decisions has had an even more serious effect in leading courts to adopt an unduly narrow construction of the statutory definition of a "labor dispute," in order to avoid the necessity for following the Statute where it overrules previous case law. The definition, which is written in very broad language, ${ }^{32}$ is of crucial importance; on its interpretation depends the scope of application of the entire Act. The dependence of the Statute upon this section is particularly clear where a union seeks to effectuate its pressure upon an employer by following his products into the hands of contractors, middlemen or customers. The union may either refuse to allow its members to handle such products, or picket establishments where they are sold or used. In either case the contractor or retailer is likely to

28. Stillwell v. Kaplan, cited supra note 25 .

29. N. Y. Civ. PrAC. ACT $\S 876$ (a)1(f) 2 and 10, prevents any relief from forbidding a person to become or remain a member of any labor organization or to urge others to do so. In addition a yellow-dog contract or an order by an employer forbidding his employees to join a union would, of course, be a violation of the right of free self organization granted by the New York Labor Relations Act. N. Y. LABOR LAw $\$ 703$. Cf. Nattonat Labor Relations Act $\$ 7,49$ Stat. 452 (1935), 29 U. S. C. $\$ 157$ (1938).

30. N. Y. Civ. Prac. Act $\$ 876(a) 1$ (a).

31. N. Y. CIV. Prac. ACT $\$ 876$ (a)1(f)5.

32. The definition of a labor dispute in the Statute is almost unbelievably complex. N. Y. Civ. Prac. AcT. $\$ 876$ (a) 10. The labor disputes definition is recognized as the "danger point" in the anti-injunction statutes. Electric Coal Co. v. Rice, $80 \mathrm{~F}$. (2d) 1 (C. C. A. 7th, 1935), 21 CoRN. L. Q. 640. The New York Legislature probably had this fact in view when it made such an elaborate effort to frame an "interpretation proof" definition. Note (1937) 50 Harv. L. Rev. 1295; Comment (1937) 15 N. Y. U. L. Q. Rev. 116; Note (1934) 34 CoL. L. Rev. 1553. 
apply for an injunction, often alleging an illegal "secondary boycott." Some courts have adopted a very restrictive attitude towards union activities under these circumstances, ${ }^{33}$ but New York has followed a more liberal rule. ${ }^{\text {a }}$ There union men ordinarily need not handle such products. The test for the legitimacy of picketing was declared in Goldfinger v. Fointuch to be "unity of interest" between the manufacturer and the third party, while in Auburn Draying Company v. Wardwell, , $^{35}$ the test was whether the union merely urged the public not to buy particular products, or whether it attempted to compel the third party to take sides by urging the public not to buy from him at all. The latter was held to be an illegal secondary boycott. This test is also implicitly included in the Goldfinger case by the court's repeated emphasis on the fact that the pickets merely urged the public not to buy a particular product. Finding that the plaintiff was in "unity of interest" with the employer party to the dispute, the court in the Goldfinger case found a labor dispute within the meaning of Section $876(a)$, since the parties were "all in the same industry."

The tests of "unity of interest" and "compulsion of third parties," which might well be considered separate, seem in practice to run together. The courts hold that where there is a secondary boycott, in the sense of a general boycott of a third party, there is neither unity of interest nor a labor dispute under the Statute. ${ }^{36}$ This seems to result from a desire to insulate the third party from injury in the greatest degree compatible with effective union pressure upon the primary party to the dispute, the manufacturer. The concept of "unity of interest" is regarded as a means by which permissible union activity may be limited to dealings in the manufacturer's particular product. Where union pressure extends to the entire business of the middleman, unity of interest is found to be lacking, and the third party and the

33. See cases collected in (1919) 6 A. L. R. 909, 934, 957.

34. Bossart v. Dhuy, 221 N. Y. 342, 117 N. E. 5\$2 (1918); Feinburg, The Nct York Law of Secondary Boycotts (1936) 6 BrookL.yN L. Rẹ. 209.

35. 227 N. Y. 1 , 124 N. E. 97 (1919), 6 A. L. R. 901.

36. Weil \& Co. v. "John Doe", 168 Mfisc. 211, 5 N. Y. S. (2d) 559 (Sup. Ct. 1938) ; American Gas Stations v. "John Doe," 250 App. Div. 227, 293 N. X. Supp. 1019 (2d Dep't 1937). These cases, involving the picketing of premises displaying nonunion made signs, pose a problem as to how, under the "particular product" emphasis, the union can picket the sign as distinct from the business which it advertises. The great majority of the cases regard this metaphysical feat as impossible and enjoin the picketing. See also People v. Bellows, 281 N. Y. 67, 22 N. E. (2d) 238 (1939). This was a criminal prosecution of persons who peacefully picketed the purchaser of such a sign. They were convicted by a magistrate who ruled that "Secondary boycotting, even though peaceful, constitutes disorderly conduct." The Court of Special Sessions, Appallate Part, reversed, holding that the ruling confused civil and criminal remedies. Pcople v. Bellows, 170 1fisc. 66, 9 N. Y.S. (2d) 850 (Sp. Sess. 1939). The Court of Appeals approved the magistrate's finding and sent the case back for a new trial, holding that secondary boycotts were illegal, there being no "unity of interest." 
union are not in the same industry for the purposes of the Statute. The same result is reached where the third party is a mere customer of the manufacturer, as in the cases involving purchasers of non-union-made neon signs. At the same time, this rather narrow construction of the labor disputes definition greatly lessens the effectiveness of the Anti-Injunction Act in these boycott cases by limiting the application of the statutory requirements to circumstances where, under pre-existing doctrines, the injunction should not issue anyway.

In some cases a somewhat narrow conception of what constitutes a labor dispute does no particular harm. An example of this is found in Thompson v. Boekhout, where it was held that there is no labor dispute if plaintiff has no present employees. ${ }^{37}$ This exception is not serious, particularly as modified in Boro Park Sanitary Live Poultry Market v. Heller, which excluded from the exception a family corporation where the stockholders worked. ${ }^{38}$ Besides, it has been held that even if there is no labor dispute as presented in the Thompson case, there still may be picketing. ${ }^{30}$

On the other hand, the use of a very narrow construction has caused some of the lower courts to decline to apply the Statute in circumstances which it seems clearly intended to cover. The Appellate Division for example, in May's Furs and Ready to Wear Company v. Bauer, ${ }^{40}$ evolved an implied exception to the Act under which, if a union engages in extreme, violent and unlawful conduct, the controversy is no longer a labor dispute and the requirements of the Act may be dispensed with. Another court held that activities growing out of a demand for concessions contrary to an existing contract could not be called a labor dispute if the enforceability of contracts was to be preserved.11 So also it was held to be no labor dispute where an employer avoided the possibility of one by closing down his plant;2 where he signed a contract on the basis of false representations ${ }^{43}$ where the union had been denied permission to do business in the state $;^{44}$ or where all of plaintiff's employees were members of a union which was a rival of the

37. 273 N. Y. 390,7 N. E. (2d) 674 (1937).

38. 280 N. Y. 481,21 N. E. (2d) 687 (1939).

39. Bieber v. Bennbaum, 168 Misc. 943,6 N. Y. S. (2d) 63 (Sup. Ct. 1938).

40. 255 App. Div. 643, 8 N. Y. S. (2d) 819 (2d Dep't 1939.)

41. Associated Flour Handlers \& Warehousemen v. Sullivan, 168 Misc. 315, 5 N. Y. S. (2d) 982 (Sup. Ct. 1938). See Jenson v. St. Paul Moving Picture Machine Operator's Local, 194 Minn. 58, 259 N. W. 811 (1935). In the Jenson case, a union picketed to induce compliance with plaintiff's contract to employ its members. The court sustained an injunction, finding that there was no labor dispute under the state antiinjunction act, because defendants had an "adequate remedy at law for damages," and hence the dispute related to damages rather than to terms and conditions of employment. Contra: Bulkin v. Sacks, 31 D. \& C. 501 (Pa. C. P. 1938).

42. Paul v. Mencher, 169 Misc. 657, 7 N. Y. S. (2d) 821 (Sup. Ct. 1937).

43. Burd \& Margalies v. Marcus, 100 N. Y. L. J. 1947 (Sup. Ct. 1938).

44. Hoffman's Vegetarian Restaurant v. Lee, 101 N. Y. L. J. 253 (Sup. Ct. 1939). 
picketing organization. ${ }^{45}$ It would appear that in all these cases, except possibly the last one, ${ }^{48}$ even if a labor dispute had been found to exist, an injunction could still issue against violence, breach of contract or fraudulent conduct. The courts in these cases attempted to aroid the Act in order to allow plaintiff to obtain his injunction without making the proof essential to the required findings, and to justify injunctions more sweeping than its terms permit.

Perhaps the most serious result of the same reliance on past decisions, which produced the narrow definition of labor disputes, is found in a recent case which crippled the provision forbidding injunctions against peaceful picketing. The Court of Appeals in Nam v. Raimist $2 \pi$ had sustained an injunction forbidding picketing where there had been violent and illegal conduct. A similar situation arose in Busch Jcwolry Company \%. Unitcd Relail Enployce's Local. ${ }^{48}$ There Justice Cotillo, on the authority of Namn w. Raimist, enjoined all picketing. He disposed of Section 876 (a) by saying it was purely procedural and declaratory, and could not forbid the injunction in the light of the constitutional provision granting jurisdiction. The decision was affirmed by the Appellate Division and again by the Court of Appeals. ${ }^{10}$ The latter court used language curiously reminiscent of the May's case, saying that if unions, deliberately and with full knowledge, advise and encourage the commission of illegal acts, they are no longer entitled to the benefits of special statutes enacted to protect them in the enjoyment of their conceded rights. ${ }^{\text {.9 }}$ This language is probably dictum, since the basis of the court's decision

45. Stalban v. Friedman, N. Y. L. J., April 3, 1939 (Sup. Ct. 1939), 34 ILL L. REv. 356. Here the granting of the injunction seems contrary not only to the requirements of the Statute, but also to pre-existing law. Stillwell Theatres v. Kaplan, 259 N. Y. 405,182 N. E. 63 (1932) cert. denicd, 298 U. S. 606 (1932).

46. See supra note 45.

47. 255 N. Y. 307,174 N. E. 690 (1931).

48. 168 Misc. 224, 5 N. Y. S. (2d) 575 (Sup. Ct. 1938), aff'd, 255 App. Div. 970, 8 N. Y. S. (2d) 819 (2d Dep't 1939). This drastic injunction not only seems unjustified under the Statute, but also failed to have a beneficial effect in the instant case. The dispute involved dragged on for a year or so with increasing bitterness. It gave rise to a multiplicity of suits of various kinds, and over thirty conferences aimed at settling it were unsuccessful. In January, 1939, the injunction came before Justice Cotillo again, on application for the six month renewal provided for in $\$ 867$ (a) 8 . He decided that a decree either way would solve nothing, and after examining European methods of settling labor disputes, secured a truce in the activities on both sides pending the report of a committee, appointed by the court to tale testimony, and, it was hoped, settle the strike. After wishing aloud for compulsory arbitration or a special system of labor courts, Justice Cotillo appointed a distinguished committee consisting of Dean Smith of the Columbia Law School, Sidney Hillman and Percy Misgnus of the Nery York Board of Trade. The proceeding is reported in 169 Misc 854, 9 N. Y. S. (2d) 167 (Sup. Ct. 1939).

49. 281 N. Y. 150,22 N. E. (2d) 320 (1939).

50. 281 N. Y. 155,22 N. E. (2d) 322 (1939). 
seems to be its belief that, in view of the background of the controversy, any picketing "would involve fraud, violence, or breach of the peace." Even on the facts, however, the decision seems unwarranted. Judge Lehman, who dissented on the basis of the words of the Statute, pointed out that the finding below was not that all picketing would involve breach of the peace, but only that it would "indicate the danger" thereof. 51 Nevertheless, so high is the authority of this court, that the "aid and comfort" which its worcls give to the doctrine of the May's case constitutes the most serious threat to date that, as a result of the declaratory doctrine and the attendant view that the Statute makes only procedural changes in the existing injunction law, the Anti-Injunction Act may be seriously crippled.

A possible solution to the threatened impairment of the New York Act is suggested by the treatment which the Wisconsin Anti-Injunction Act has enjoyed at the hands of the Wisconsin courts. The Wisconsin Statute ${ }^{62}$ is similar to that of New York, but the Wisconsin courts, not having such a large body of judicially-evolved injunction law before them, ${ }^{53}$ found it easier to interpret the Statute as not only altering procedure, but also granting new substantive rights to labor. An example of this view is found in the leading Wisconsin case upon the interpretation of the Anti-Injunction Statute, American Furniture Company v. International Brotherhood. ${ }^{54}$ In this case the union sought by picketing to compel the unionization of a shop in which the union had no present members, and in which the workers apparently did not desire to join the union, even though the employer did not object to their doing so. The court refused to enjoin the picketing, holding that the controversy was within the statutory definition of a labor dispute. The legislature was held to have declared in the Statute the lawftulness of acts which in its judgment were necessary in order to give labor an economic weapon which would balance the power of the employer.

An important consideration which caused the New York courts to hesitate in giving this construction to their Statute was the fear that such substantive changes in the rights of private parties in labor disputes would be a violation of the due process clause in the state and federal constitutions. ${ }^{\text {t5 }}$ Trua. v. Corrigan, ${ }^{50}$ which struck down an Arizona statute, modeled after the Clayton Act labor provisions, was cited as authority for this view. The

51. 281 N. Y. $157,159,22$ N. E. (2d) 322,324 (1939).

52. Wis. Stat. (1937) $\S 103.56-63$, Wis. Laws (1931) c. 376.

53. The Wisconsin Court in David Ables \& Sons Co. v. Moglio, 200 Wis. 153, 228 N. W. 123 (1929), commented on this lack of injunction cases, ascribing it to the mutual respect for each other's rights exhibited by capital and labor in the state.

54. American Furniture Co. v. International Brotherhood, 222 Wis. $338,268 \mathrm{~N}$. W. 250 (1936). 1935).

55. Aberdeen Restaurant v. Gotfried, 158 Misc. 785, 285 N. Y. Supp. 382 (Sup. Ct.

56. 257 U. S. 312 (1921). 
Supreme Court of the United States surmounted this difficulty in Scm $v$. The Tile Layer's Protective Union, where the Wisconsin Act, as interpreted by the Wisconsin court, was sustained. ${ }^{57}$ MIr. Justice Brandeis relied in his opinion on the fact that the substantive changes alleged to have been made did not go much further than previous doctrines already warranted. The Court distinguished Truax v. Corrigan on the ground that the statute there involved purported to legalize violent and unlawful conduct.

Since, then, the Supreme Court permits substantive changes so long as they do not greatly modify existing essential rights, the New York Court of Appeals, which has never specifically indorsed the declaratory doctrine, is now in a position where it can adopt the Wisconsin view. This would not involve granting substantive rights much beyond those already conceded; but it would remedy the problems of interpretation, and of compliance with the New York Constitution, which under the declaratory doetrine have created so much trouble. The objection created by the limitation which the New York Constitution, as interpreted, places on procedural clinges would disappear; since clearly the legislature, if it may legalize a course of conduct, may also deprive the courts of "jurisdiction" to punish for it.ss Under the Wisconsin view, there would be no inducement to, and no authority for, an unduly narrow construction of the labor dispute section of the New York Statute; and the confusion resulting from the mingling of the vague criteria of pre-existing law with the statutory terms could be avoided by interpreting the Statute, as Wisconsin does, as in substance a labor code, in itself sufticient in all normal situations to guide and govern the course of judicial action in the vexed field of the labor injunction.

57. 301 U. S. 468 (1937), aff'g. 222 Wis. 3\$3, 268 N. W. 270 (1936).

58. This point was made in answer to the constitutional objection in American Furniture Co. v. International Brotherhood, 222 Wis. 338, 365, 268 N. W. 250,263 (1936). 